\title{
THE COMPOSITE MODELS APPLICATION FOR ELASTIC MODULUS OF POLY(ETHYLENE TEREPHTHALATE)/ POLY(BUTYLENE TEREPHTHALATE) BLENDS DESCRIPTION
}

\section{Muslim Abdulakhovich Mikitaev}

Candidate of Chemical Sciences, Senior Researcher,

Department of Organic Chemistry and Macromolecular Compounds,

Kabardino-Balkarian State University named after H. M. Berbekov

I dolbin@mail.ru

Chernyshevskogo St., 175, 360004 Nalchik, Russian Federation

\section{Georgiy Vladimirovich Kozlov}

Senior Researcher, Department of Organic Chemistry and Macromolecular Compounds,

Kabardino-Balkarian State University named after H. M. Berbekov

I_dolbin@mail.ru

Chernyshevskogo St., 175, 360004 Nalchik, Russian Federation

Abdulakh Kasbulatovich Mikitaev

Doctor of Chemical Sciences, Professor,

Department of Organic Chemistry and Macromolecular Compounds,

Kabardino-Balkarian State University named after H. M. Berbekov

I_dolbin@mail.ru

Chernyshevskogo St., 175, 360004 Nalchik, Russian Federation

\section{Marina Izraylevna Artsis}

Candidate of Chemical Sciences, Researcher,

Department of Biological and Chemical Physics of Polymers,

Institute of Biochemical Physics named after N. M. Emanuel, RAS

chembio@sky.chph.ras.ru

Kosygina St., 4, 119334 Moscow, Russian Federation

\section{Gennadiy Efremovich Zaikov}

Doctor of Chemical Sciences, Professor, Head of Department of Biological and Chemical Physics of Polymers, Institute of Biochemical Physics named after N. M. Emanuel, RAS

chembio@sky.chph.ras.ru

Kosygina St., 4, 119334 Moscow, Russian Federation 


\begin{abstract}
The quantitative interpretation of the extreme dependence of elastic modulus on the composition of poly(ethylene terephthalate)/poly(butylene terephthalate) blends has been proposed. At this, the authors apply the basics of the percolation theory and fractal analysis. It has been shown that the extreme increase in elastic modulus is due to the corresponding growth of shear strength of blends components during the autohesional bonding. It is noted that the micromechanical models do not give the adequate description of the indicated effect.
\end{abstract}

Key words: blend, micromechanical model, percolation, fractal analysis, elastic modulus, interfacial adhesion.

\section{Introduction}

The maximum of elastic modulus at equal contents of components in blends is one of the outstanding features of the blends of poly(ethylene terephthalate)/poly(butylene terephthalate) (PET/PBT) $[2 ; 3]$. In addition, it is important to note, the elastic moduli of initial PET and PBT are practically equal - the discrepancy between them makes up $\sim 1 \%$ by absolute value, that is smaller than their determination experimental error. The authors $[2 ; 3]$ supposed that variation of elastic modulus of blends PET/PBT at composition change was due to blends components miscibility variation. It is significant that PET and PBT are miscible partly, namely, amorphous phase miscibility (single glass transition temperature) can be realized, but crystalline phases nonmiscibility (two crystallization temperatures) is observed [2]. In the work [6] it has been proposed to consider semicrystalline polymers as composites, in which amorphous phase is played by matrix role and filler role - by crystallites. However, in such treatment the extreme change of crystalline phase characteristics is necessary, whereas regardless of blends $\mathrm{PET} / \mathrm{PBT}$ production mode these characteristics are changed monotonously and not very significantly [13]. Nevertheless, the blends $\mathrm{PET} / \mathrm{PBT}$ can be considered as polymer/ polymeric composites [11], particularly at the condition, that one polymeric phase is dispersed in another as disperse particles with the size of $0.2-1.5 \mathrm{mcm}[10]$. With appreciation of the stated above considerations the purpose of the present work is the treatment of blends PET/ PBT as polymer/polymeric composites within the frameworks of micromechanical [1] and percolation [5] models for quantitative description of the extreme dependence of their elastic modulus on composition.

\section{Experimental}

The industrial production polymers were used: PET PELPET, grade G5801 (intrinsic viscosity $[\eta]=0.8 \mathrm{dL} / \mathrm{g}$ ), procured from firm Reliance Industries Ltd (India), and PBT LUPOX, grade GP$1000([\eta]=1.0 \mathrm{dL} / \mathrm{g})$, supplied by firm LG Polymers India Pvt Ltd (India). PET and PBT pellets were manually mixed and dried at temperature $393 \mathrm{~K}$ for 8 hours in a hot air circulating oven [2].

The blends with PET:PBT ratio of $80: 20$, $70: 30,60: 40,50: 50,40: 60$ and $20: 80$ by weight were prepared by components mixing in melt using twin-screw extruder Haake Rheocord 9000 of mark TW100 at the screw rate rotation of $40 \mathrm{rpm}$ in the range of temperatures of 423 $533 \mathrm{~K}$. Then the extrudate was water cooled and granulated. The extruded pellets were molded into standard mechanical tests specimens by injection molding mode on molding machine Boolani Industries Ltd., production of India, within the range of temperatures 493-553 $\mathrm{K}$ [2].

The mechanical tests of blends PET/PBT on three-pointed bending were carried out on universal testing machine LR-50K, Lloyds Instrument according to ASTM 790M-90 at temperature $293 \mathrm{~K}$ and cross-head speed of $2.8 \mathrm{~mm} / \mathrm{min}$ [2].

\section{Results and Discussion}

Let us consider the micromechanical models application of the description of blends PET/PBT elastic modulus. In the simplest from the possible cases two models were proposed [1]. For the case of parallel arrangement the uniform strain in both phases is assumed and upper boundary of elastic modulus of blends $E_{b l}^{\text {up }}$ is given as follows [1]: 


$$
E_{b l}^{\mathrm{up}}=E_{n} \varphi_{n}+E_{m} \varphi_{m}
$$

where $E_{n}$ and $E_{m}$ are elastic moduli of filler and matrix, respectively, $\varphi_{n}$ and $\varphi_{m}$ are volume contents of filler and matrix, accordingly $\left(\varphi_{m}=1-\varphi_{n}\right)$.

In case of series arrangement the stress is assumed to be uniform in them and the lower boundary of elastic modulus of blends $E_{b l}^{1}$ is determined according to the equation [1]:

$$
E_{b l}^{1}=\frac{E_{n} E_{m}}{E_{n} \varphi_{m}+E_{m} \varphi_{n}} .
$$

At the condition $E_{n}=E_{m}$, which is true for the considered blends, the equations (1) and (2) give the trivial result: $E_{b l}^{u p}=E_{b l}^{1}=E_{n}=E_{m}$, i. e. the indicated equations are not capable of describing the experimentally observed maximum on the dependence of elastic modulus on composition for blends PET/PBT $[2 ; 3]$. This is explained by the fact, that all micromechanical models require fulfillment of the condition $E_{n}>E_{m}$ for their correct application. One more obvious deficiency of micromechanical models is apriori used in them assumption of perfect adhesion between phases of composite that is far from always being fulfilled for real composites [9].

The percolation model gives the following relationship for $E_{b l}$ determination [5]:

$$
\frac{E_{b l}}{E_{m}}=1+11\left(\varphi_{n}\right)^{1.7} .
$$

The relationship (3) does not also take into consideration interfacial adhesion level between composite phases and therefore the authors [11] modified it as follows:

$$
\frac{E_{b l}}{E_{m}}=1+11\left(b_{\boldsymbol{\alpha}} \varphi_{n}\right)^{1.7}
$$

where $b_{\alpha}$ is a dimensionless parameter, characterizing the interfacial adhesion level (in case of perfect adhesion $b_{\alpha}=1.0$ [11]).

By its physical essence interfacial adhesion between PET and PBT represents the formation of autohesional bonding, shear strength of which $\tau_{c}$ can be determined as follows [15]:

$$
\tau_{c}=6.28 \times 10^{-5} N_{c}^{3.83} \mathrm{MPa}
$$

where $N_{c}$ is the number of intersections (contacts) of macromolecular coils in boundary layer of two polymers (in the considered case-PET and PBT).
Within the frameworks of fractal analysis the value $N_{c}$ can be determined according to the relationship [14]:

$$
N_{c} \sim R_{g}^{2 D_{f}-d}
$$

where $R_{g}$ is gyration radius of macromolecular coil, $D_{f}$ is its fractal dimension, $d$ is the dimension of Euclidean space, in which a fractal is considered (it is obvious that in our case $d=3$ ).

The value $D_{f}$ is calculated according to the following technique. First Poisson's ratio value $v$ was estimated with the aid of the formula [8]:

$$
\frac{\sigma_{Y}}{E_{b l}}=\frac{1-2 v}{6(1+v)}
$$

where $\sigma_{Y}$ is blend yield stress.

Then the structure of fractal dimension $d_{f}$ for blends PET/PBT was determined according to the equation [4]:

$$
d_{f}=(d-1)(1+v) \text {. }
$$

And at last for linear polymers the value $D_{f}$ is determined as follows [7]:

$$
D_{f}=\frac{2 d_{f}}{3} \text {. }
$$

In Fig. 1 the relations between parameter $b_{\alpha}$, determined with the aid of the equation (4), and shear strength $\tau_{c}$ of autohesional contact PETPBT is adduced. As it was expected from the most general considerations, between parameters $b_{\alpha}$ and $\tau_{c}$ the linear correlation is observed, which passes through coordinates origin described by the following empirical equation:

$$
b_{\alpha}=4.6 \tau_{c} \text {. }
$$

The combination of equations (4) and (10) allows to obtain the following relationship for determination of blends PET/PBT elastic modulus:

$$
E_{b l}=E_{m}\left[1+11\left(4.6 \tau_{c} \varphi_{n}\right)^{1.7}\right] .
$$

It is obvious that $\mathrm{PBT}$ relative fraction at its content smaller than 50 mass \% and PET relative fraction at its very same content is 
accepted as $\varphi_{n}$. In Fig. 2 the comparison of theoretically calculated according to the equation (11) $E_{b l}^{T}$ and experimentally obtained $E_{b l}$ elastic modulus values for blends PET/PBT is adduced, which show their good correspondence (the average discrepancy between $E_{b l}^{T}$ and $E_{b l}$ makes up less than $5 \%$ ).

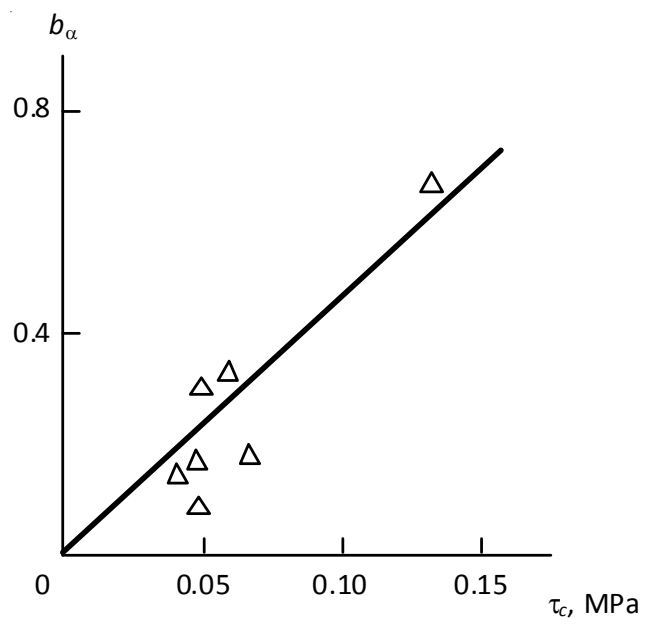

Fig. 1. The relation between parameter $b_{\alpha}$, characterizing interfacial adhesion level, and shear strength $\tau_{c}$ of autohesional bonding for blends PET/PBT

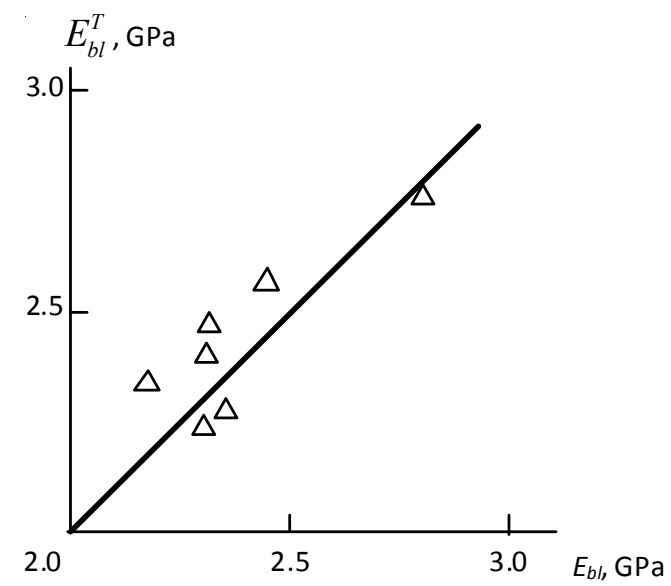

Fig. 2. The comparison of theoretically calculated according to the equation (11) $E_{b l}^{T}$ and experimentally measured $E_{b l}$ values of elastic modulus for PET/PBT blends

\section{Conclusions}

Thus, the present work results have demonstrated that micromechanical models cannot describe correctly the dependence of elastic modulus on composition for blends PET/
PBT. This is due to non-fulfilment of the conditions, obligatory for the indicated models: essentially larger value of filler elastic modulus in comparison with corresponding characteristic for polymer matrix and assumption of perfect interfacial adhesion (as far as we know, the SatoFurukawa model [12] is a sole micromechanical model taking into consideration the real level of interfacial adhesion in composites). The considered blends elastic modulus enhancement is due to the growth of contacts number of macromolecular coils of PET and PBT in boundary layer and corresponding enhancement of interfacial adhesion level. The proposed model in which the percolation theory and fractal analysis notions are used, allows precise quantitative description of the experimental data.

\section{Acknowledgements}

The present research has been performed within the complex project on creation of hi-tech production with the participation of the Russian higher educational institution, Tanneta JSC, the Ministry of Education and Science of the Russian Federation of February 12, 2013 No. 02.G25.31.0008 (Resolution of the Government of the Russian Federation No. 218).

\section{REFERENCES}

1. Ahmed S., Jones F.R. A Review of Particulate Reinforcement Theories for Polymer and Composites. J. Mater. Sci., 1990, vol. 25, pp. 4933-4932.

2. Aravinthan G., Kale D.D. Blends of Poly(ethylene terephthalate) and Poly(butylene terephthalate). J. Appl. Polymer Sci., 2005, vol. 98, pp. $75-82$.

3. Avramova N. Amorphous Poly(ethylene terephthalate)/poly(buthylene terephthalate) Blends: Miscibility and Properties. Polymer, 1995, vol. 36, pp. 801-808.

4. Balankin A.S. Synergetics of Deformable Body. Moscow, Ministerstvo oborony SSSR Publ., 1991. 404 p. (in Russian).

5. Bobryshev A.N., Kozomazov V.N., Babin L.O., Solomatov V.I. Synergetics of Composite Materials. Lipetsk, NPO ORIUS, 1994. $154 \mathrm{p}$.

6. Kardos J.L., Raisoni J. The Potential Mechanical Response of Macromolecular Systems A Composite Analogy. Polymer Engineering and Science, 1975, vol. 15, pp. 183-190. 


\title{
ТЕХНИКО-ТЕХНОЛОГИЧЕСКИЕ ИННОВАЦИИ
}

7. Kozlov G.V., Mikitaev A.K., Zaikov G.E. The Fractal Physics of Polymer Synthesis. Toronto, New Jersey, Apple Academic Press, 2014. 359 p.

8. Kozlov G.V., Sanditov D.S. Anharmonic Effects, and Physical and Mechanical Properties of Polymers. Novosibirsk, Nauka Publ., 1994. 261 p. (in Russian).

9. Kozlov G.V., Yanovskiy Yu.G., Zaikov G.E. Structure and Properties of Particulate-Filled Polymer Composites: The Fractal Analysis. New York, Nova Science Publishers Inc., 2010. 282 p.

10. Maruhashi Y., Tida S. Transparency of Polymer Blends. Polymer Engineering Science, 2001, vol. 41, pp. 1987-1995.

11. Mikitaev A.K., Kozlov G.V., Zaikov G.E. Polymer Nanocomposites: Variety of Structural
Forms and Applications. New York, Nova Science Publishers, Inc., 2008. 319 p.

12. Sato Y., Furukawa J. Polymerization of Aldehydes and Oxides. Rubber Chem. Techn., 1963, vol. 36, pp. 1081-1089.

13. Szostak M. Calculation of the Formation and Migration Energies for a Vacancy in the Naphthalene Crystal. Mol Cryst. Liq. Cryst., 2004, vol. 416, pp. 209-215.

14. Vilgis T.A. Flory Theory of Polymeric Fractals - Intersection, Saturation and Condensation. Physica A, 1988, iss. 153, pp. 341-354.

15. Yakhyaeva Kh.Sh., Kozlov G.V., Magomedov G.M. The Dependence of Interfacial Adhesion Level on Carbon Nanotubes. Fundamental Problems of Modern Engineering Science, 2014, iss. 11, pp. 206-209.

\section{ЗАВИСИМОСТЬ МОДУЛЯ УПРУГОСТИ ОТ СОСТАВА СМЕСИ В КОМПОЗИЦИОННЫХ МОДЕЛЯХ ПОЛИ(ЭТИЛЕН ТЕРЕФТАЛАТА)/ПОЛИ(БУТИЛЕН ТЕРЕФТАЛАТ)}

\author{
Муслим Абдулахович Микитаев
}

Кандидат химических наук,

старший научный сотрудник кафедры органической химии и высокомолекулярных соединений, Кабардино-Балкарский государственный университет им. Х. М. Бербекова I_dolbin@mail.ru ул. Чернышевского, 175, 360004 г. Нальчик, Российская Федерация

\section{Георгий Владимирович Козлов}

Старший научный сотрудник кафедры органической химии и высокомолекулярных соединений, Кабардино-Балкарский государственный университет им. Х. М. Бербекова I_dolbin@mail.ru ул. Чернышевского, 175, 360004 г. Нальчик, Российская Федерация

\section{Абдулах Касбулатович Микитаев}

Доктор химических наук, профессор кафедры органической химии и высокомолекулярных соединений, Кабардино-Балкарский государственный университет им. Х. М. Бербекова I_dolbin@mail.ru ул. Чернышевского, 175, 360004 г. Нальчик, Российская Федерация

\section{Марина Израйлевна Арцис}

Кандидат химических наук,

научный сотрудник отдела биологической и химической физики полимеров,

Институт биохимической физики им. Н. М. Эмануэля РАН

chembio@sky.chph.ras.ru

ул. Косыгина, 4, 119334 г. Москва, Российская Федерация 


\section{Геннадий Ефремович Заиков}

Доктор химических наук, профессор, заведующий отделом биологической и химической физики полимеров, Институт биохимической физики им. Н. М. Эмануэля РАН chembio@sky.chph.ras.ru ул. Косыгина, 4, 119334 г. Москва, Российская Федерация

Аннотация. Была показана прямая зависимость модуля упругости от состава смесей поли(этилен терефталата)/поли(бутилен терефталат), которая может быть использована для перколяции и фрактального анализа. Показано, что модуль упругости показывает экстремальный рост, что обусловлено соответствующим ростом сдвиговой прочности смеси компонентов системы. Микромеханические модели не дают адекватного описания указанного эффекта.

Ключевые слова: смесь, микромеханические модели перколяции, фрактальный анализ, модуль упругости, межфазная адгезия. 